\title{
Preparation and luminescent properties of a rare earth borate red light-emitting material
}

\author{
B. YING, W.G. SHENG* \\ Shenyang University of Chemical Technology, Shenyang 110142, P.R. China
}

\begin{abstract}
A new hydrated rare earth borate $\mathrm{K}_{2} \mathrm{O} \cdot \mathrm{CaO} \cdot 4 \mathrm{~B}_{2} \mathrm{O}_{3} \cdot 12 \mathrm{H}_{2} \mathrm{O}: \mathrm{Eu}$ was prepared by water solution method. The crystal structure, morphology, luminescence properties were investigated via XRD, IR, TG-DSC and SEM, respectively, and it was shown that one single crystal was obtained via spontaneous crystallization. The luminescent properties were also investigated by F-4600 spectrophotometer.
\end{abstract}

Keywords: borate; solution method; rare earth doping; luminescence

\section{Introduction}

Luminescent materials with borates as the host are considered as very useful in practice and preferred materials for the high definition and projective television, due to their low synthesizing temperature, simple preparation conditions and high luminescent brightness [1-6]. Borate doped $\mathrm{Eu}^{3+}$ shows intense red emission lines at $616 \mathrm{~nm}$ corresponding to the forced ED transition $\left({ }^{5} \mathrm{D}_{0} \rightarrow{ }^{7} \mathrm{~F}_{2}\right)$ of $\mathrm{Eu}^{3+}$. Now, the borate phosphors doped $\mathrm{Eu}^{3+}$, such as $\quad(\mathrm{Y}, \mathrm{Gd}) \mathrm{BO}_{3}: \mathrm{Eu}, \mathrm{YAl}_{3}\left(\mathrm{BO}_{3}\right)_{4}: \mathrm{Eu} \quad$ and $\mathrm{BaZr}\left(\mathrm{BO}_{3}\right)_{2}: \mathrm{Eu}$ attract attention as red emitting phosphors for plasma display panels [7-11].

As water molecules or $\mathrm{OH}^{-}$contained in a product have a quenching effect on the material luminescence, the present study mainly concentrates on anhydrous borate luminescent materials. The reports about hydrated borates are rare. In fact, as early as in 1965, Xie et al. [12] put forward that most of hydrated borates show luminous performance. In 2008, Liu et al. [13] prepared nanometer materials of $\mathrm{MgBO}_{2}(\mathrm{OH}): \mathrm{Eu}(\mathrm{Y})$ by hydrothermal method. Under UV excitation, $\mathrm{MgBO}_{2}(\mathrm{OH}) \mathrm{Eu}$ nanobelts showed strong red emission and the emission spectrum intensity increased greatly with

*E-mail: bywx@163.com the $\mathrm{Eu}^{3+}, \mathrm{Y}^{3+}$ co-doping. $\mathrm{MgBO}_{2}(\mathrm{OH}): \mathrm{Eu}$ can be applied in fluorescent transparent panels. Huang et al. [14] synthesized $\mathrm{SrB}_{2} \mathrm{O}_{4} \cdot 4 \mathrm{H}_{2} \mathrm{O}: \mathrm{Eu}$ by liquid co-precipitation method. The material had stronger luminescence in the UV region and could be used as a new hydrated borate matrix for light-emitting material. The researches showed that borate compounds formed by alkali ( $\mathrm{Li}, \mathrm{Na}, \mathrm{K}, \mathrm{Rb}, \mathrm{Cs}$ ) or alkaline earth metals $(\mathrm{Mg}, \mathrm{Ca}, \mathrm{Sr}, \mathrm{Ba})$ and rare earth elements are beneficial to reduce the concentration quenching effect and are expected to solve partially the problems such as color cast and luminous efficiency [15-20].

In the present work, a new rare earth hydrous borate $\mathrm{K}_{2} \mathrm{O} \cdot \mathrm{CaO} \cdot 4 \mathrm{~B}_{2} \mathrm{O}_{3} \cdot 12 \mathrm{H}_{2} \mathrm{O}: \mathrm{Eu}(\mathrm{KCB}: \mathrm{Eu})$ has been realized by water solution method. We describe the structure of $\mathrm{KCB}: \mathrm{Eu}$ and report its synthesis, crystal growth, IR ,TG-DSC and the luminescence properties.

\section{Experimental}

\subsection{Synthesis}

$\mathrm{KOH}, \mathrm{H}_{3} \mathrm{BO}_{3}, \mathrm{CaCl}_{2} \cdot 2 \mathrm{H}_{2} \mathrm{O}$ and $\mathrm{Eu}_{2} \mathrm{O}_{3}$ were mixed at $35{ }^{\circ} \mathrm{C}$ at a mass ratio of 25:50:7.43 with a stirring speed of $400 \mathrm{rpm}$, in a $500 \mathrm{~mL}$ three-neck flask. At the rate of temperature drop of $2{ }^{\circ} \mathrm{C}$ per day from $35{ }^{\circ} \mathrm{C}$, single crystals of KCB:Eu began to generate after 3 days. 
Characteristic crystallization began in a few days at room temperature. The resulting white crystals of KCB:Eu were recovered by filtration, washed by deionized water, and dried in a vacuum dryer to a solid mass, at room temperature.

\subsection{Characterization}

The compound was characterized by X-ray powder diffraction (D8 Advance, $\mathrm{CuK} \alpha 1,40 \mathrm{kV}$, $40 \mathrm{~mA}$ ), FT-IR spectroscopy recorded on $\mathrm{KBr}$ pellets in the $400 \mathrm{~cm}^{-1}$ to $4000 \mathrm{~cm}^{-1}$ region on a Nicolet 470 spectrometer at room temperature. The emission and excitation spectra were measured by F-4600 spectrophotometer at room temperature.

\subsection{Determination of crystal structure}

A white crystal of $\mathrm{KCB}: \mathrm{Eu}$ with approximate dimension $3 \mathrm{~mm} \times 1 \mathrm{~mm} \times 1 \mathrm{~mm}$ was selected for single crystal X-ray diffraction. Diffraction data were collected at $293 \mathrm{~K}$ on an automated Bruker Smart-1000 CCD four-circle diffractometer with graphite monochromatized $\mathrm{MoK} \alpha$ radiation $(\lambda=0.71073 \AA)$. All calculations were performed with programs from the SHELXTL crystallographic software package. Final lest-squares refinement was performed on $\mathrm{F}_{\mathrm{O}}{ }^{2}$ with the data having $\mathrm{F}_{\mathrm{o}}^{2} \geqslant 2 \sigma\left(\mathrm{F}_{\mathrm{o}}^{2}\right)$.

\section{Results and discussion}

\subsection{Crystal structure}

Fig. 1 shows the XRD patterns of KCB (JCPDS Card No. 76-1013) and KCB:Eu crystals. The diffraction peaks in the patterns correspond well with the expected positions. Adding $\mathrm{Eu}^{3+}$ has not changed the crystal morphology obviously. Both crystals are found to belong to orthorhombic system, with a space group of $\mathrm{P} 22_{1} 2_{1} 2_{1}, \mathrm{Z}=4$. Their unit cell parameters are shown in Table 1 . It can be seen that the two crystal lattices exhibit slight different distortions and the cell parameters $a, b$ and c become smaller due to Eu addition. It may be caused by $\mathrm{Eu}^{3+}\left(\mathrm{r}_{\mathrm{Eu}}{ }^{3+}=0.0950 \mathrm{~nm}\right)$ which could replace $\mathrm{Ca}^{2+}$ ion $\left(\mathrm{r}_{\mathrm{Ca}}{ }^{2+}=0.099 \mathrm{~nm}\right)$ in the structure. The SEM photographs of the sample crystals are shown in Fig. 2, which clearly reveals the orthorhombic structure of single crystal. The crystal surface becomes coarser with the rare earth ion adding.

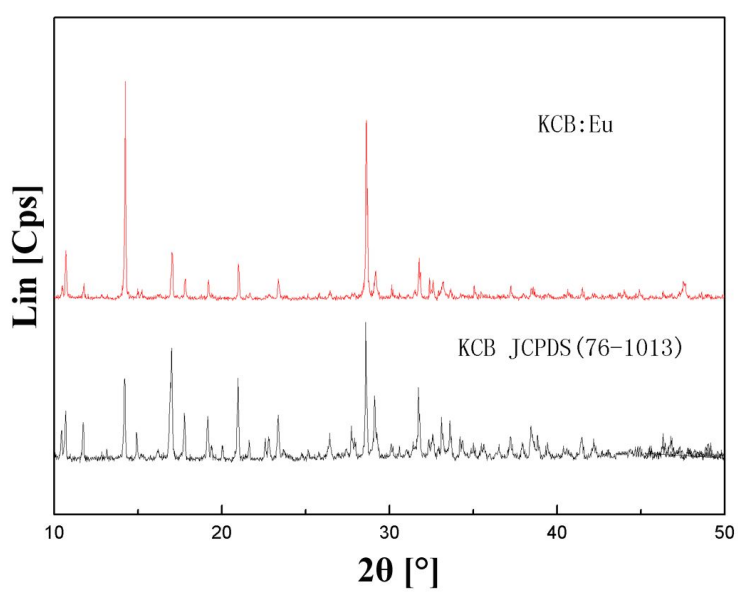

Fig. 1. XRD patterns of KCB and KCB:Eu.

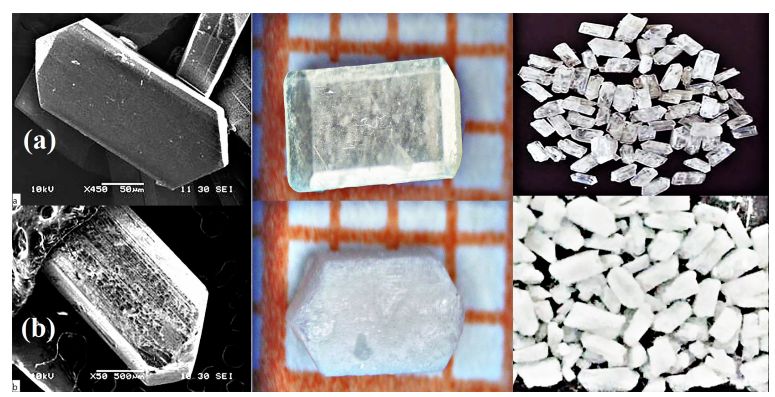

Fig. 2. The SEM and photographs of KCB (a), and $\mathrm{KCB}: \mathrm{Eu}(\mathrm{b})$ at different magnifictions.

\subsection{FT-IR spectroscopy}

The FT-IR spectra scanned between $500 \mathrm{~cm}^{-1}$ to $4000 \mathrm{~cm}^{-1}$ in the transmittance mode are shown in Fig. 3.

The bands at $3204 \mathrm{~cm}^{-1}$ to $3612 \mathrm{~cm}^{-1}$ are the stretching vibrations of the $\mathrm{O}-\mathrm{H}$ group. The bands at $1635 \mathrm{~cm}^{-1}$ and $1684 \mathrm{~cm}^{-1}$ are assigned to the $\mathrm{H}-\mathrm{O}-\mathrm{H}$ bending modes, which shows that this compound contains crystalline water. The bands at $1345 \mathrm{~cm}^{-1}, 1402 \mathrm{~cm}^{-1}$ and $1455 \mathrm{~cm}^{-1}$ belong to $\mathrm{B}-\mathrm{O}$ asymmetric stretching in $\mathrm{BO}_{3}$. The bands at $1294 \mathrm{~cm}^{-1}$ and $1164 \mathrm{~cm}^{-1}$ can be assigned to $\mathrm{B}-\mathrm{O}-\mathrm{H}$. The bands at $1002 \mathrm{~cm}^{-1}, 1040 \mathrm{~cm}^{-1}$ 
Table 1. The lattice parameters of KCB:Eu

\begin{tabular}{lccccccc}
\hline \multicolumn{1}{c}{ Compound } & $\mathrm{a}[\mathrm{nm}]$ & $\mathrm{b}[\mathrm{nm}]$ & $\mathrm{c}[\mathrm{nm}]$ & $\alpha\left[^{\circ}\right]$ & $\beta\left[^{\circ}\right]$ & $\gamma\left[^{\circ}\right]$ & $\mathrm{V}\left[\mathrm{nm}^{3}\right]$ \\
\hline \hline $\mathrm{K}_{2} \mathrm{Ca}\left[\mathrm{B}_{4} \mathrm{O}_{5}(\mathrm{OH})_{4}\right]_{2} \cdot 8 \mathrm{H}_{2} \mathrm{O}$ & 1.65597 & 1.24030 & 1.15801 & 90 & 90 & 90 & 2.36471 \\
$\mathrm{~K}_{2} \mathrm{Ca}\left[\mathrm{B}_{4} \mathrm{O}_{5}(\mathrm{OH})_{4}\right]_{2} \cdot 8 \mathrm{H}_{2} \mathrm{O}: \mathrm{Eu}$ & 1.64990 & 1.23480 & 1.15090 & 90.2054 & 90.1923 & 90 & 2.34472 \\
\hline
\end{tabular}

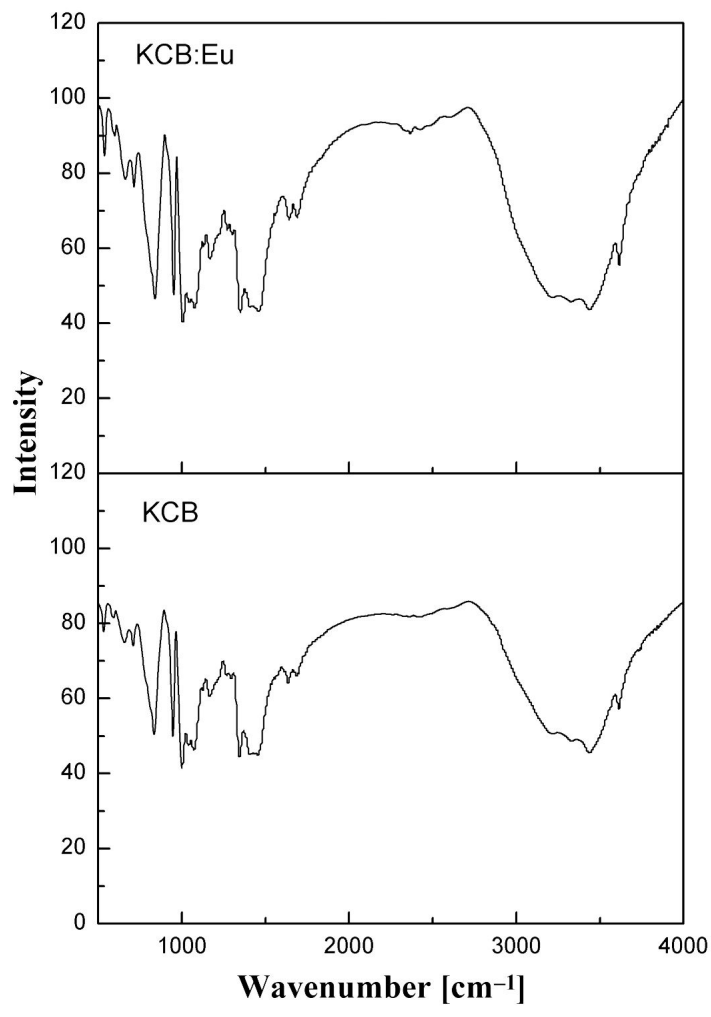

Fig. 3. FT-IR spectra of KCB and KCB:Eu.

and $1071 \mathrm{~cm}^{-1}$ are the asymmetric and symmetric stretching modes of $\mathrm{B}-\mathrm{O}$ in $\mathrm{BO}_{4}$, respectively. The band at $591 \mathrm{~cm}^{-1}$ is the characteristic peak of the tetraborate anion of $\left(\mathrm{B}_{4} \mathrm{O}_{5}(\mathrm{OH})_{4}\right)$ [21]. The band at $460 \mathrm{~cm}^{-1}$ is the bending mode of $\mathrm{B}-\mathrm{O}$ in $\mathrm{BO}_{4}$. Such results confirm the existence of $\left(\mathrm{B}_{4} \mathrm{O}_{5}(\mathrm{OH})_{4}\right)$ groups in the structure, which is consistent with the above structural determination. Eu-O vibration frequency has not caused any microstructural changes in the sample.

\subsection{Thermal behavior}

The thermal gravity-differential scanning calorimetric (TG-DSC) analysis of KCB:Eu has been performed using NETZSCH STA 449C simultaneous thermal analyzer (Fig. 4). There is a sharp endothermic peak at about $100.9{ }^{\circ} \mathrm{C}$ in the DSC curve, which corresponds to the melting point of KCB:Eu. There is also another sharp exothermic peak at $683.1{ }^{\circ} \mathrm{C}$, which corresponds to the recrystallization phase.

Two step weight losses appeared in the TG curve (equation 1). One step lost $8 \mathrm{H}_{2} \mathrm{O}$ at $80{ }^{\circ} \mathrm{C}$ to $120{ }^{\circ} \mathrm{C}$ with a mass loss up to $21.8 \%$ (The loss rate of $8 \mathrm{H}_{2} \mathrm{O}$ is $22.3 \%$ in theory) and another step lost $4 \mathrm{H}_{2} \mathrm{O}$ at $120^{\circ} \mathrm{C}$ to $600{ }^{\circ} \mathrm{C}$ with a mass loss up to $10.2 \%$ :

$$
\begin{aligned}
& \mathrm{K}_{2} \mathrm{O} \cdot \mathrm{CaO} \cdot 4 \mathrm{~B}_{2} \mathrm{O}_{3} \cdot 12 \mathrm{H}_{2} \mathrm{O}: \mathrm{Eu} \underset{-8 \mathrm{H}_{2} \mathrm{O}}{\longrightarrow} \\
& \mathrm{K}_{2} \mathrm{O} \cdot \mathrm{CaO} \cdot 4 \mathrm{~B}_{2} \mathrm{O}_{3} \cdot 3 \mathrm{H}_{2} \mathrm{O}: \mathrm{Eu} \underset{-4 \mathrm{H}_{2} \mathrm{O}}{\longrightarrow} \\
& \mathrm{K}_{2} \mathrm{O} \cdot \mathrm{CaO} \cdot 4 \mathrm{~B}_{2} \mathrm{O}_{3}: \mathrm{Eu}
\end{aligned}
$$

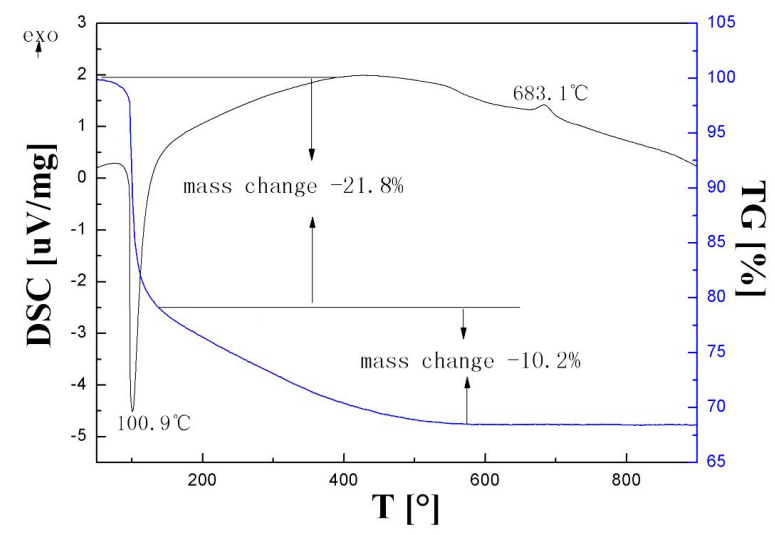

Fig. 4. TG DSC curves of KCB:Eu.

\subsection{Emission and excitation spectra}

Fig. 5 shows the excitation spectra of KCB:Eu at a wavelength of $616 \mathrm{~nm}$. One broad excitation band in the range of $220 \mathrm{~nm}$ to $350 \mathrm{~nm}$ is 
attributed to the charge-transfer (CTB) transition of $\mathrm{Eu}^{3+}-\mathrm{O}^{2-}$ (CTB) and $\mathrm{B}^{3+}-\mathrm{O}^{2-}$ (CTB). The sharp peaks in the $350 \mathrm{~nm}$ to $500 \mathrm{~nm}$ ultravioletvisible range are due to the $4 \mathrm{f}-4 \mathrm{f}$ transition of $\mathrm{Eu}^{3+}$. There are two groups of the strongest sharp excitation spectrum lines located at $467 \mathrm{~nm}\left({ }^{7} \mathrm{~F}_{0} \rightarrow{ }^{5} \mathrm{D}_{2}\right)$ and $395 \mathrm{~nm}\left({ }^{7} \mathrm{~F}_{0} \rightarrow{ }^{5} \mathrm{~L}_{6}\right)$ nearby. It shows that KCB:Eu luminescent materials can be effectively stimulated by $395 \mathrm{~nm}$ ultraviolet light and $467 \mathrm{~nm}$ visible light.

Emission spectrum under $395 \mathrm{~nm}$ excitation is shown in Fig. 6. There are two emission peaks of $\mathrm{Eu}^{3+}$ near $591 \mathrm{~nm}\left({ }^{5} \mathrm{D}_{0} \rightarrow{ }^{7} \mathrm{~F}_{1}\right)$ and $616 \mathrm{~nm}$ $\left({ }^{5} \mathrm{D}_{0} \rightarrow{ }^{7} \mathrm{~F}_{2}\right)$. The main emission peak at $616 \mathrm{~nm}$ belongs to the typical ${ }^{5} \mathrm{D}_{0} \rightarrow{ }^{7} \mathrm{~F}_{2}$ red emission energy level transition of $\mathrm{Eu}^{3+}$. The excitation wavelength at $395 \mathrm{~nm}$ is matched with the output wavelength of the UV and blue light which is widely used now.

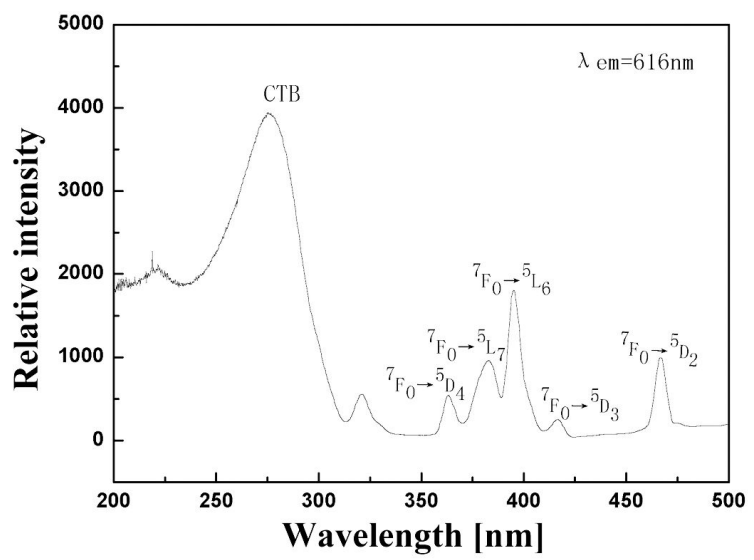

Fig. 5. The excitation spectrum of KCB:Eu monitored at $616 \mathrm{~nm}$.

The emission spectra (at $616 \mathrm{~nm}$ ) of KCB:xEu $(\mathrm{x}=0.012,0.024,0.036,0.048)$ under $395 \mathrm{~nm}$ excitation are shown in Fig. 7. The emission intensity of phosphors increases with an increase in $\mathrm{Eu}^{3+}$ concentration. When $\mathrm{x}$ is greater than $3.6 \mathrm{wt} . \%$, the material luminous intensity decreases. When $\mathrm{Eu}^{3+}$ content is low, the average distance of adjacent $\mathrm{Eu}^{3+}$ in the lattice matrix is longer, the cross relaxation almost never happens. With the excessive amount of $\mathrm{Eu}^{3+}$ doping, the average distance between adjacent $\mathrm{Eu}^{3+}$ is short and the cross

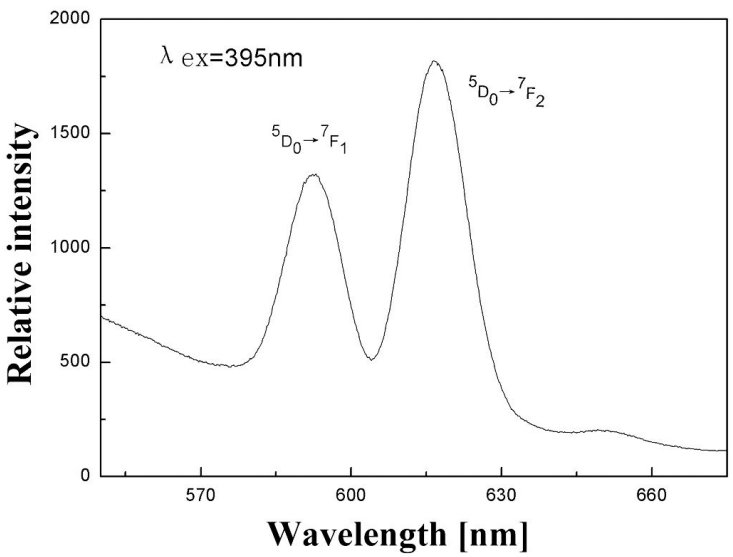

Fig. 6. The emission spectrum of KCB:Eu under $395 \mathrm{~nm}$ excitation.

relaxation becomes very easy. The energy of $\mathrm{Eu}^{3+}$ dissipates in the form of radiation in the lattice matrix, which makes the concentration quenching phenomenon happen.

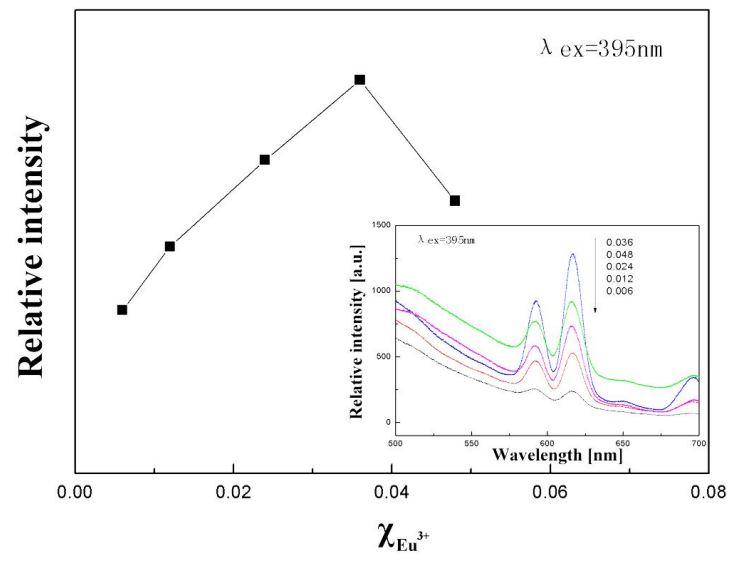

Fig. 7. The influence of $\mathrm{Eu}^{3+}$ concentration on luminescence intensity of KCB: Eu.

\section{Conclusions}

New rare earth borates KCB:Eu have been synthesized by water solution method and the crystals have been produced via spontaneous crystallization. They crystallized in orthorhombic space group $\mathrm{P} 2{ }_{1} 2_{1} 2_{1}$ and had a fine shape. The sample melted at $100.9{ }^{\circ} \mathrm{C}$ and had two-step weight losses, one step lost $8 \mathrm{H}_{2} \mathrm{O}$ at $80{ }^{\circ} \mathrm{C}$ to $120{ }^{\circ} \mathrm{C}$ and the other lost $4 \mathrm{H}_{2} \mathrm{O}$ at $120{ }^{\circ} \mathrm{C}$ to $600{ }^{\circ} \mathrm{C}$. Under 
UV excitation, the $\mathrm{Eu}^{3+}$ doped $\mathrm{KCB}$ revealed a strong red-light emission peak located at about $616 \mathrm{~nm}$. The results are significant to promoting research and development of hydration borate matrix in luminescent material applications.

\section{References}

[1] Hou S., Yu F.P., TANG Y.X., Zhang S.J., ZhaO X., IEEE T. Ultrason. Fer, 61 (2014), 561.

[2] Zhang Z.J., Jin T.T., XU M.M., HuAng Q.Z., LI M.R., ZHAO J.T., Inorg. Chem., 54 (2015), 969.

[3] You W.X., Lai F.Q., LiU X.L., Jiang H.H., LiaO J.S., WAng P., BIN Y., Opt. Spectrosc.+, 116 (2014), 62.

[4] Yi X., Cong R., Zhou Z., Yang T., New J. Chem., 38 (2014), 122.

[5] QIU X., Sasaki K., Hirajima T., IDETA K., MiYaWAKi J., Chem. Eng. J., 225 (2013), 664.

[6] Kurumaji T., Ohgushi K., Tokura Y., Phys. Rev. B, 89 (2014), 1719.

[7] SzczeszaK A., Grzyb T., BARszcz B., NAGiRnYi V., Kotlov A., Lis S., Inorg. Chem., 52 (2013), 4934.

[8] Shubham S., Aparna M., Niroj K.S., ShanTANU K., BiBhuti B., RSC Adv., 15 (2015), 11009.

[9] Çelik G., Kurtulus F., Acta Phys. Pol. A, 125 (2014), 325.
[10] Chen W.P., Zhou A.H., J. Phys. Chem. C, 116 (2012), 24748.

[11] Song W., Huang G., Dai R., Wang Z., Zhang Z., J. Chem. Mater. C, 10 (2015), 2405.

[12] XiE X.D., Zheng J.P., LiU L.B., Borate minerals, Science Press, Beijing, 1965.

[13] LiU J.P., Li Y.Y., HuAng X.T., Li Z.K., Li G.Y., Zeng H.B., Chem. Mater., 20 (2008), 250.

[14] Huang H.S., LiU ZH., Acta Chim. Sinica, 70 (2012), 247.

[15] Wang Z., Jing Q., Zhang M., Pan S., Yang Z., ZHANG H., Inorg. Chem. Commun., 49 (2014), 63.

[16] Sahare P.D., Singh M., Kumar P., J. Lumin., 160 (2015), 158.

[17] Bai X.Y., Zhang G.C., Fu P.Z., J. Solid State Chem., 180 (2007), 1792.

[18] Wang Z.J., LiU H.Y., ZANG K., Chinese J. Lumin., 31 (2010), 49.

[19] Song L.M., GaO J.H., Yang X.H., Huang X.W., LIU G.Q., Chinese. J. Struct. Chem., 29 (2010), 1309.

[20] Yang Z.P., Song Z.F., Ma X., Wang H.F., GuO Y.N., WEN J.W., Chinese J. Lumin., 31 (2010), 724.

[21] Huang H.S., Chen Z.S., LiU ZH., Thermochim. Acta, 459 (2007), 130.

Received 2016-09-14 Accepted 2018-05-05 